\title{
The Mechanism of Bicarbonate Secretion in Rabbit Ileum Exposed to Choleragen
}

\author{
KenNeth A. HubeL \\ From the Department of Medicine, University of Iowa, Iowa City, Iowa 52242
}

A B S T R A C T Bicarbonate may be secreted into the intestinal lumen in cholera because: $\mathrm{HCO}_{3}{ }^{-}$ions are transported, or because $\mathrm{OH}^{-}$ions accumulate and react with dissolved $\mathrm{CO}_{2}$ to form $\mathrm{HCO}_{3}{ }^{-}$. If $\mathrm{HCO}_{3}{ }^{-}$ions are transported into the lumen from the interstitial fluid, lumenal $\mathrm{PCO}_{2}$ should increase $\left(\mathrm{HCO}_{3}^{-} \rightleftharpoons \mathrm{OH}^{-}+\mathrm{CO}_{2}\right)$; if $\mathrm{OH}^{-}$accumulates, $\mathrm{PcO}_{2}$ should diminish. Net movement of $\mathrm{H}_{2} \mathrm{O}$, and $\mathrm{HCO}_{3}^{-}$, and changes in $\mathrm{pH}$ and $\mathrm{PCO}_{2}$ in lumenal fluid were studied in adjacent segments of rabbit ileum in vivo, one of which was exposed to choleragen. $4 \mathrm{~h}$ after exposure, segments were drained and infused with gassed Krebs-Henseleit solution whose $\mathrm{PCO}_{2}$ exceeded arterial $\mathrm{PCO}_{2}$. After 45 min, fluid was collected anaerobically from control and cholera segments. Among 13 cholera segments, lumenal $\mathrm{PCO}_{2}$ diminished by a mean of 8.4 torr and was less than femoral arterial blood in six instances. In the paired control segments, mean $\mathrm{PcO}_{2}$ increased by 4.4 torr, and was always greater than arterial Pcos. Dilution could not account for the low $\mathrm{PCO}_{2}$ in cholera segments because in hypertonic solutions that caused water to move into the lumen, the $\mathrm{Pco}_{2}$ did not differ from control values obtained with isotonic solutions. The results suggest that $\mathrm{OH}^{-}$ accumulation (by addition of $\mathrm{OH}^{-}$or removal of $\mathrm{H}^{+}$) causes $\mathrm{HCO}_{3}{ }^{-}$secretion in cholera. This does not result from secretion of some other base (e.g., HPO- ${ }^{-}$), because $\mathrm{HCO}_{s}^{-}$accounts for most of the base in the lumenal fluid. The $\mathrm{PCO}_{2}$ changes suggest that $\mathrm{OH}^{-}$ reacts with $\mathrm{CO}_{2}$ at the cell-lumen interface, but reaction at the cell-interstitial fluid interface cannot be excluded.

\section{INTRODUCTION}

Patients with cholera have diarrhea in which massive amounts of water and salt are lost. The concentration of bicarbonate in the fecal fluid may be four times greater than that of the plasma, and the loss of this base results in metabolic acidosis (1). The bicarbonate may accumu-

Received for publication 18 June 1973 and in revised form 29 October 1973. late in the lumenal fluid of the small intestine because of two processes: either $\mathrm{HCO}_{3}^{-}$ions are transported into the lumen, or $\mathrm{OH}^{-}$ions accumulate in the lumen and react with dissolved $\mathrm{CO}_{2}$ to form $\mathrm{HCO}_{3}{ }^{-}$. By measuring the change in lumenal fluid $\mathrm{PCO}_{2}$ in the intestine exposed to cholera toxin, it is possible to infer which of these processes predominates: if $\mathrm{HCO}_{3}{ }^{-}$ions move into the lumenal fluid, the $\mathrm{PCO}_{2}$ should increase because $\mathrm{HCO}_{3}{ }^{-}$dissociates and shifts the reaction, $\mathrm{OH}^{-}+\mathrm{CO}_{2} \rightleftharpoons$ $\mathrm{HCO}_{3}{ }^{-}$, to the left. However, $\mathrm{OH}^{-}$accumulation in the lumen should reduce $\mathrm{PCO}_{2}$ as $\mathrm{OH}^{-}$reacts with $\mathrm{CO}_{2}$ and removes it from solution. The following studies suggest that in the rabbit ileum exposed to cholera toxin, the latter mechanism predominates.

\section{METHODS}

Rabbits of either sex, weighing $2-2.5 \mathrm{~kg}$, were anesthetized by injecting pentobarbital into an ear vein. A femoral vein and femoral artery were cannulated with polyethylene tubing filled with a solution of saline and heparin. Two adjacent segments of ileum, each $20 \mathrm{~cm}$ long, were constructed by ligating the proximal ends with black silk after the lumen was washed with saline. A metal cannula attached to a three-way stopcock was then inserted into the distal end of each segment and tied into place. The distal segment terminated about $3 \mathrm{~cm}$ from the cecum. The abdomen was then closed with metal clips. A tracheostomy tube was inserted and connected to a respirator.

Study 1: determination of $\mathrm{PCO}_{2}$ of fluid in ileal segments exposed to choleragen or saline. Choleragen (Wyeth 001 , Wyeth Laboratories, Inc., Div. of American Home Products Corp., Philadelphia, Pa.), $2.0 \mathrm{mg}$, was dissolved in 4 $\mathrm{ml}$ of saline and infused into the lumen of one of the ileal segments. The location, i.e., proximal or distal, of the cholera segment was alternated in successive studies. The same volume of saline without choleragen was infused into the "control" segment. $4 \mathrm{~h}$ then passed, during which the $\mathrm{pH}$ and $\mathrm{PCO}_{2}$ of femoral arterial blood were periodically determined. After $4 \mathrm{~h}$, the abdomen was opened and fluid was gently expressed from the segments. Fluid was rarely present in the control segment.

A solution of the following composition was then infused into each segment $(\mathrm{mM}): \mathrm{NaCl} 120, \mathrm{KCl} 4.5, \mathrm{NaHCO}_{3} 25$, $\mathrm{Na}_{2} \mathrm{HPO}$, 1.8, $\mathrm{NaH}_{2} \mathrm{PO}_{4} 0.2, \mathrm{MgSO}_{4} 1.0$, mannitol 20. The 
TABLE I

Net Movement of $\mathrm{H}_{2} \mathrm{O}$ and $\mathrm{HCO}_{3}{ }^{-}$, and Final $\mathrm{HCO}_{3}-$ Concentrations of Lumenal Fluid of Cholera and Control Ileal Segments

\begin{tabular}{|c|c|c|c|c|c|c|}
\hline \multirow{2}{*}{$\begin{array}{l}\text { Study } \\
\text { no. }\end{array}$} & \multicolumn{2}{|c|}{$\Delta \mathrm{H}_{2} \mathrm{O}$} & \multicolumn{2}{|c|}{$\triangle \mathrm{HCO}_{\mathbf{3}}-$} & \multicolumn{2}{|c|}{$\begin{array}{l}\text { Final lumen } \mathrm{HCO}_{3}- \\
\text { concentration }\end{array}$} \\
\hline & Control & Cholera & Control & Cholera & Control & Cholera \\
\hline & \multicolumn{2}{|c|}{$m l$} & \multicolumn{2}{|c|}{ 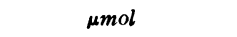 } & \multicolumn{2}{|c|}{$m M$} \\
\hline 1 & $-3^{*}$ & 5 & -6 & 426 & 43.7 & 58.9 \\
\hline 2 & -1 & 3 & 61 & 358 & 39.8 & 65.7 \\
\hline 3 & -2 & 3 & -45 & 336 & 28.0 & 63.2 \\
\hline 4 & 0 & 5 & 251 & 488 & 62.1 & 65.8 \\
\hline 5 & -3 & 4 & -43 & 443 & 35.1 & 68.5 \\
\hline 6 & -1 & 1 & 138 & 218 & 51.7 & 63.2 \\
\hline 7 & -4 & 3 & -68 & 340 & 33.4 & 62.3 \\
\hline 8 & 1 & 5 & 37 & 291 & 27.0 & 43.7 \\
\hline 9 & 0.5 & 3.5 & 241 & 408 & 55.3 & 67.6 \\
\hline 10 & -1 & 3.5 & 3 & 422 & 30.6 & 70.0 \\
\hline 11 & 0 & 3.5 & 234 & 361 & 59.8 & 62.4 \\
\hline 12 & -2 & 4.5 & -17 & 507 & 33.4 & 72.1 \\
\hline 13 & -1 & 3 & 142 & 513 & 54.3 & 88.3 \\
\hline Mean & -1.3 & 3.6 & 71 & 393 & 42.6 & 65.5 \\
\hline $\mathrm{SD}$ & 1.5 & 1.1 & 116 & 87 & 12.6 & 9.8 \\
\hline$P$ & \multicolumn{2}{|c|}{$<0.001$} & \multicolumn{2}{|c|}{$<0.001$} & \multicolumn{2}{|c|}{$<0.001$} \\
\hline
\end{tabular}

* The sign indicates movement into $(+)$ or out of $(-)$ the lumen in the columns showing net movement of $\mathrm{H}_{2} \mathrm{O}$ and $\mathrm{HCO}_{3}{ }^{-}$.

fluid, equilibrated with $5.4 \% \quad \mathrm{CO}_{2}-94.6 \% \mathrm{O}_{2}$, had a $\mathrm{pH}$ of about 7.4 and an osmolality of $303 \mathrm{mosmol} / \mathrm{kg}$. $7 \mathrm{ml}$ were infused into the control and $4 \mathrm{ml}$ into the cholera segment in order to yield similar quantities at the end of the study period. In other studies $4 \mathrm{ml}$ were infused into each segment; the results were similar regardless of the initial volume in the control segment. After the fluid remained in the segments for $45 \mathrm{~min}$, the abdomen was opened and the fluid was gently expressed into $10-\mathrm{ml}$ syringes. Air introduced into the collected fluid from the dead space of the stopcock and syringe did not exceed $20 \mu 1$ in volume and could have introduced an error of no more than $0.5 \%$ (about 0.2 torr) in the $\mathrm{PCO}_{2}$ determinations. Gas collected from the segments at the end of the study period was considered to be in equilibrium with the collected fluid. The volume of fluid was measured, and the syringe was capped to prevent loss of $\mathrm{CO}_{2}$. Samples of blood $(4 \mathrm{ml})$ from the femoral artery and vein were collected in heparinized syringes immediately before and after the 45-min study period, and a sample of portal vein blood was usually obtained by direct puncture after all other specimens had been collected. After the rabbit was sacrificed, the ileal segments were excised, freed of mesentery, and weighed. A standard weight (a hemostat) was then clamped to the segment, which was allowed to stretch by gravity for about $30 \mathrm{~s}$. The length was then measured with a rule calibrated in centimeters.

Study 2. Influence of fluid movement on $\mathrm{Pco}_{\mathrm{s}}$. The lower $\mathrm{PCO}_{2}$ of the fluid in cholera segments might be caused by simple dilution, because fluid was secreted into the cholera segments and was usually absorbed from the control segments. To determine whether fluid movement contributed to the $\mathrm{PCO}_{2}$ change, two adjacent ileal segments were pre- pared in the manner described in study 1 , except that choleragen was not added to either segment. To assure that the animals were in approximately the same physiological condition as those of the prior study, $4 \mathrm{~h}$ were allowed to pass before the test fluids were infused. Then $4 \mathrm{ml}$ of hypertonic fluid was infused into one of the ileal segments, and $7 \mathrm{ml}$ of isotonic fluid into the other. After $45 \mathrm{~min}$, the segments were drained, and the volume, $\mathrm{pH}$, and $\mathrm{PCO}_{2}$ of the fluid were measured. Blood was collected in the same manner as in study 1 . The isotonic fluid (300 mosmol $/ \mathrm{kg}$ ) was a solution of $160 \mathrm{mM} \mathrm{NaCl}$; the hypertonic fluid was identical to the isotonic fluid except that it was made hypertonic ( $454 \mathrm{mosmol} / \mathrm{kg}$ ) by adding mannitol.

The volume of fluid from the ileal segments was measured to the nearest $0.5 \mathrm{ml}$ with the calibrated collection syringe. Fluid $\mathrm{pH}$ and $\mathrm{PCO}_{2}$ were measured with an Instrumentations Laboratory, Inc., (Lexington, Mass.) ultramicro $\mathrm{pH}$ and $\mathrm{PCO}_{2}$ electrode system. The $\mathrm{PCO}_{2}$ meter was standardized after every determination and the $\mathrm{pH}$ meter was standardized frequently. Samples of fluid for $\mathrm{pH}$ determination were obtained directly from the syringe immediately after the cap was removed by dipping the plastic aspiration tube at least $\frac{1}{2}$ in into the fluid. The fluid was then aspirated into the $\mathrm{pH}$ electrode until it overfilled the cuvette of $\mathrm{pH}$-sensitive glass. After $30 \mathrm{~s}$, the $\mathrm{pH}$ reading was made to the nearest 0.01 unit. After the $\mathrm{pH}$ cuvette was filled, a small amount of fluid was expressed from the syringe containing the ileal fluid; the cuvette of the $\mathrm{CO}_{2}$ electrode was then filled until fluid appeared at the exit port. The $\mathrm{PCO}_{2}$ reading was made exactly $2 \mathrm{~min}$ after the sample was introduced. Under these conditions, the mean difference $( \pm \mathrm{SD})$ between eight duplicate $\mathrm{PCO}_{2}$ 
determinations was 0.7 torr $( \pm 0.6)$, and of the $\mathrm{pH}$ determinations was $0.01( \pm 0.01)$. Bicarbonate concentrations were calculated with the Henderson-Hasselbalch equation with a $\mathrm{pK}^{\prime}$ of 6.1 . The net movement of bicarbonate was calculated as follows: $J_{\text {net }} \mathrm{HCO}_{3}{ }^{-}=V_{t} C_{f}-V_{t} C_{t} . V$ and $C$ represent volume and concentration, and the subscripts $f$ and $i$ stand for final and initial.

To determine whether $\mathrm{HCO}_{3}{ }^{-}$accounted for the base in the lumenal fluid from the study segments, the concentration of base in samples of lumenal fluid was measured by back titration. To $1.00 \mathrm{ml}$ of lumenal fluid was added $1.00 \mathrm{ml}$ of $0.100 \mathrm{M} \mathrm{HCl}$ and $5 \mathrm{ml}$ of distilled water. The mixture was stirred with a magnetic bar for several min to facilitate the loss of $\mathrm{CO}_{2}$, and was then titrated to $\mathrm{pH}$ 7.00 with $0.100 \mathrm{M} \mathrm{NaOH}$. The $\mathrm{HCO}_{3}{ }^{-}$concentration of the fluid was calculated with the Henderson-Hasselbalch equation from measurement of total $\mathrm{CO}_{2}$, made with the Natelson Microgasometer (Scientific Industries, Inc. Queens Village, N. Y.), and $\mathrm{pH}$.

Statistical significance of mean differences was assessed with the Student $t$ test for paired samples.

\section{RESULTS}

Study 1: determination of $P_{C o 2}$ of fluid in ileal segments exposed to choleragen or saline. The control and cholera segments were of similar length. The mean $( \pm \mathrm{SD})$ length of segments exposed to choleragen was $20.8 \mathrm{~cm}( \pm 2.6)$; segments exposed to saline measured $20.7 \mathrm{~cm}( \pm 3.1)$. Although there was considerable variation, the rabbits were generally in a state of mild

TABLE II

$\mathrm{PCO}_{2}$ of Fluid from Cholera and Control Segments Compared with $\mathrm{PCO}_{2}$ of Initial Infusion Fluid, Mean Arterial $\mathrm{PCO}_{2}$, and $\mathrm{PCO}_{2}$ of Portal Vein Blood

Sampled at End of Study Period

\begin{tabular}{cccccc}
\hline $\begin{array}{c}\text { Study } \\
\text { no. }\end{array}$ & $\begin{array}{c}\text { Final } \\
\text { cholera }\end{array}$ & $\begin{array}{c}\text { Final } \\
\text { control }\end{array}$ & $\begin{array}{c}\text { Initial } \\
\text { infusion }\end{array}$ & $\begin{array}{c}\text { Mean } \\
\text { arterial }\end{array}$ & $\begin{array}{c}\text { Final } \\
\text { portal } \\
\text { vein }\end{array}$ \\
\hline & & & torr & & \\
1 & 26.4 & 33.3 & 36.6 & 21.0 & 29.2 \\
2 & 22.9 & 34.8 & 36.1 & 23.8 & 40.0 \\
3 & 29.0 & 44.5 & 38.4 & 25.8 & 36.7 \\
4 & 29.5 & 38.4 & 37.9 & 27.4 & 32.7 \\
5 & 26.1 & 44.4 & 34.7 & 34.4 & 37.9 \\
6 & 21.0 & 36.7 & 34.1 & 16.4 & 26.0 \\
7 & 24.3 & 35.9 & 33.3 & 23.5 & 29.8 \\
8 & 28.3 & 42.0 & 35.5 & 24.5 & 34.1 \\
9 & 25.8 & 35.0 & 34.2 & 29.3 & 38.1 \\
10 & 39.5 & 48.7 & 35.8 & 32.2 & 39.3 \\
11 & 32.9 & 47.6 & 36.6 & 37.8 & 42.8 \\
12 & 25.7 & 41.3 & 41.1 & 35.2 & 37.4 \\
13 & 30.0 & 45.4 & 36.4 & 33.1 & 44.7 \\
Mean & 27.8 & 40.6 & 36.2 & 28.0 & 36.1 \\
SD & 4.7 & 5.2 & 2.1 & 6.3 & 5.5 \\
\hline
\end{tabular}

Final cholera vs. mean arterial, NS; final cholera vs. initial infusion, $P<0.001$; final cholera vs. final control, $P<0.001$; final control vs. mean arterial $P<0.001$.

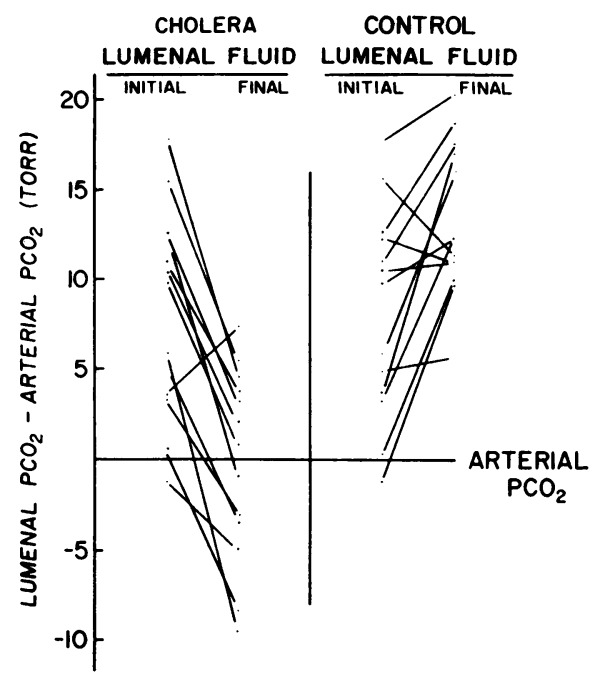

Figure 1 Changes in $\mathrm{PCO}_{2}$ of lumenal fluid in cholera and control segments relative to mean arterial $\mathrm{Pco}_{2}$. The horizontal line represents mean arterial $\mathrm{PCO}_{2}$. Points above the line represent lumenal $\mathrm{PCO}_{2}$ values greater than mean arterial $\mathrm{PCO}_{2}$. In 6 of 13 studies, $\mathrm{PCO}_{2}$ of lumenal fluid in cholera segments diminished to values less than mean arterial $\mathrm{PCO}_{2}$.

compensated metabolic acidosis: the mean $( \pm \mathrm{SD}) \mathrm{pH}$ and bicarbonate concentration of femoral arterial blood sampled in 13 rabbits immediately before and after the study period was $7.37( \pm 0.08)$ and $18.2 \mathrm{mM}( \pm 6.8)$.

As expected, the net movement of water was into the lumen of the cholera segments, and out of the lumen in the control segments (Table I). Significantly more $\mathrm{HCO}_{3}{ }^{-}$accumulated in the cholera than in the control segments, and in every instance, the final concentration of lumenal $\mathrm{HCO}_{3}{ }^{-}$in the cholera segments exceeded that in the paired control.

The mean $\mathrm{PCO}_{2}$ of the fluid infused into the cholera and control segments (initial infusion) was similar to the mean $\mathrm{PCO}_{2}$ of portal vein blood, and with one exception, was always greater than the mean $\mathrm{PCO}_{2}$ of femoral arterial blood (Table II). By the end of the 45-min test period, the lumenal $\mathrm{PcO}_{2}$ in the cholera and control segments differed significantly: the mean $\mathrm{PCO}_{2}$ of cholera fluid declined to that of arterial blood, and the mean $\mathrm{PCO}_{2}$ of control fluid increased (Fig. 1).

In the lumenal fluid, the magnitude of the initial $\mathrm{PCO}_{2}$ influenced its final value (Fig. 1). Among the 13 cholera segments, the final lumenal $\mathrm{PCO}_{2}$ fell below that of arterial blood in six studies. The initial $\mathrm{PCO}_{2}$ values in five of those studies clustered most closely to that of femoral arterial blood. To put it another way, if the initial $\mathrm{PCO}_{2}$ of the lumenal fluid of the cholera segment was near that of arterial blood, the final $\mathrm{PCO}_{2}$ value was usually less than that of arterial blood.

Lumenal $\mathrm{PCO}_{2}$ diminished by a mean of 8.4 torr in 


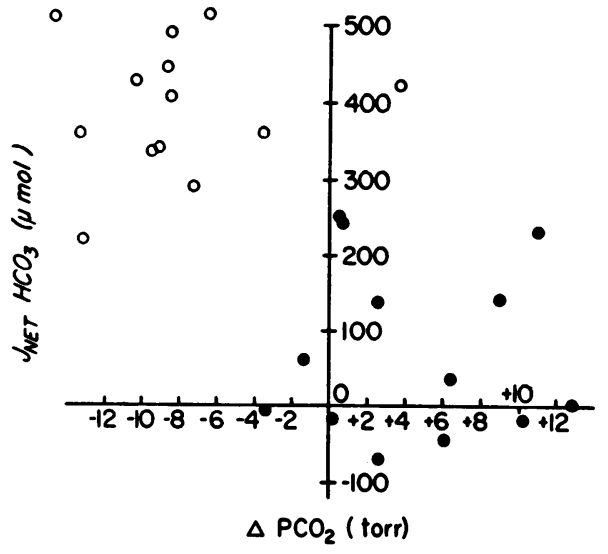

FIgURE 2 The relationship between $J_{\text {net }} \mathrm{HCO}_{3}^{-}$(vertical axis) and the change in lumenal $\mathrm{PCO}_{2}$ (final $\mathrm{PCO}_{2}-$ initial $\mathrm{PCO}_{2}$ ) in cholera and control segments.

cholera segments. However, in control segments, the mean final $\mathrm{Pco}_{2}$ was 4.4 torr higher than the initial infusion value, and in no instance was the final $\mathrm{PCO}_{2}$ less than that of arterial blood.

The change in lumenal fluid $\mathrm{PCO}_{2}$ was roughly proportional to the rate and direction of net $\mathrm{HCO}_{3}{ }^{-}$movement (Fig. 2). In the cholera segments, where the rate of $\mathrm{HCO}_{3}^{-}$secretion was greatest, lumenal fluid $\mathrm{PCO}_{2}$ diminished; in the control segments, where $\mathrm{HCO}_{3}^{-}$was either absorbed or was secreted at lower rates, lumenal $\mathrm{PCO}_{2}$ increased.

Among the factors that might reduce the $\mathrm{PCO}_{2}$ of $\mathrm{lu}$ menal fluid in the cholera segments is dilution. In study

TABLE III

Net Movement of $\mathrm{H}_{2} \mathrm{O}$ and $\mathrm{HCO}_{3}^{-}$, and Final $\mathrm{HCO}_{3}{ }^{-}$ Concentrations of Lumenal Fluid that was Initially Either Isotonic or Hypertonic

\begin{tabular}{|c|c|c|c|c|c|c|}
\hline \multirow{2}{*}{$\begin{array}{l}\text { Study } \\
\text { no. }\end{array}$} & \multicolumn{2}{|c|}{$\Delta \mathrm{H}_{2} \mathrm{O}$} & \multicolumn{2}{|c|}{$\triangle \mathrm{HCO}_{3}-$} & \multicolumn{2}{|c|}{$\begin{array}{l}\text { Final lumen } \mathrm{HCO}_{3}- \\
\text { concentration }\end{array}$} \\
\hline & Iso & Hyper & Iso & Hyper & Iso & Hyper \\
\hline & \multicolumn{2}{|c|}{$m l$} & \multicolumn{2}{|c|}{$\mu \mathrm{mol}$} & \multicolumn{2}{|c|}{$m M$} \\
\hline 1 & -2.5 & 0.5 & 125 & 148 & 27.6 & 32.9 \\
\hline 2 & -1.5 & 1.5 & 144 & 178 & 26.2 & 32.4 \\
\hline 3 & -1.0 & 1.0 & 113 & 109 & 18.9 & 21.7 \\
\hline 4 & 0.5 & 5.0 & 182 & 428 & 24.2 & 47.6 \\
\hline 5 & -0.5 & 0.0 & 270 & 116 & 41.6 & 29.1 \\
\hline 6 & -2.5 & 2.5 & 175 & 339 & 38.8 & 52.1 \\
\hline 7 & -0.5 & 1.0 & 305 & 164 & 46.9 & 32.8 \\
\hline 8 & -3.0 & 2.5 & 120 & 301 & 30.0 & 46.3 \\
\hline Mean & -1.4 & 1.8 & 179 & 223 & 31.8 & 36.9 \\
\hline SD & 1.2 & 1.6 & 72 & 118 & 9.6 & 10.5 \\
\hline$P$ & \multicolumn{2}{|c|}{$<0.01$} & \multicolumn{2}{|c|}{ NS } & \multicolumn{2}{|c|}{ NS } \\
\hline
\end{tabular}

TABLE IV

$\mathrm{PCO}_{2}$ of Fluid from Ileal Segments Containing Isotonic or Hypertonic Fluid Compared with $\mathrm{PCO}_{2}$ of Initial Infusion Fluid, Mean Arterial $\mathrm{PCO}_{2}$, and $\mathrm{PCO}_{2}$ of Portal Vein Blood Sampled at End of Study Period

\begin{tabular}{|c|c|c|c|c|c|c|}
\hline \multirow{2}{*}{$\begin{array}{c}\text { Study } \\
\text { no. }\end{array}$} & \multicolumn{2}{|c|}{ Isotonic } & \multicolumn{2}{|c|}{ Hypertonic } & \multirow{2}{*}{$\begin{array}{c}\text { Mean } \\
\text { arterial }\end{array}$} & \multirow{2}{*}{$\begin{array}{c}\text { Final } \\
\text { portal } \\
\text { vein }\end{array}$} \\
\hline & Initial & Final & Initial & Final & & \\
\hline & \multicolumn{6}{|c|}{ torr } \\
\hline 1 & 31.7 & 34.8 & 32.1 & 32.3 & 27.1 & 30.7 \\
\hline 2 & 30.4 & 24.0 & 31.6 & 29.6 & 26.4 & 31.7 \\
\hline 3 & 30.0 & 34.5 & 31.6 & 40.5 & 29.5 & 35.0 \\
\hline 4 & 34.0 & 29.2 & 32.1 & 22.3 & 29.9 & 33.1 \\
\hline 5 & 32.6 & 37.2 & 31.6 & 40.4 & 32.3 & 40.5 \\
\hline 6 & 30.8 & 40.7 & 31.1 & 37.9 & 29.9 & 39.3 \\
\hline 7 & 31.6 & 27.1 & 33.1 & 31.4 & 25.7 & 34.2 \\
\hline 8 & 32.3 & 47.6 & 32.6 & 41.5 & 38.1 & 40.5 \\
\hline Mean & 31.7 & 34.4 & 32.0 & 34.5 & 29.9 & 35.6 \\
\hline SD & 1.3 & 7.7 & 0.6 & 6.7 & 4.0 & 4.0 \\
\hline
\end{tabular}

Final isotonic vs. mean arterial, $P<0.05$; Final hypertonic vs. mean arterial, $P=0.05$; Final isotonic vs. final hypertonic, NS.

2, we determined the influence of water movement on the final $\mathrm{PCO}_{2}$ of lumenal fluid.

Study 2: influence of fluid movement on $P_{\text {cos }}$. The length of the segments infused with hypertonic fluid was almost identical to that of isotonic segments 21.8 $( \pm 2.1)$ and $21.9 \mathrm{~cm}( \pm 2.0)$. The mean $\mathrm{pH}$ of the arterial blood was $7.41( \pm 0.03)$ and its mean $\mathrm{HCO}^{-}$concentration was $19 \mathrm{mM}( \pm 3.3)$.

There was a net movement of water into the lumen of $1.8 \mathrm{ml}( \pm 1.6)$ in the hypertonic segments whereas in the isotonic segments, $1.4 \mathrm{ml}( \pm 1.2)$ was absorbed (Table III). The quantity and concentration of $\mathrm{HCO}_{s}^{-}$ that accumulated in the lumenal fluid of isotonic and hypertonic segments did not differ significantly.

Water movement had no significant effect on the

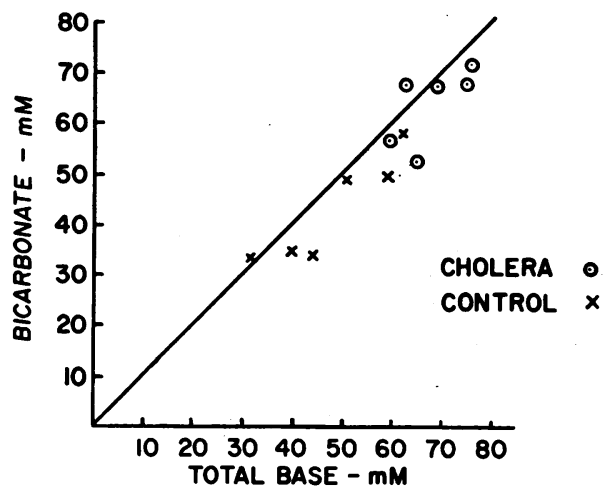

FIGURE 3 Relationship of bicarbonate ion concentration to the concentration of total base in lumenal fluid of cholera and control segments. Bicarbonate accounts for most of the base present. 
final Pco2 of lumenal fluid (Table IV). Thus, it is unlikely that the movement of water into the lumen in the cholera segments in study 1 reduced the lumenal $\mathrm{PCO}_{2}$ to values less than that of control segments and femoral arterial blood.

Total base and bicarbonate concentration of lumenal fluid. Bicarbonate accounts for most, but not all, of the total amount of base in the lumenal fluid of cholera and control segments (Fig. 3). The two values that fall to the left of the line of ideal correlation must be explained by experimental error, since bicarbonate content cannot exceed the content of total base.

\section{DISCUSSION}

Bicarbonate may accumulate in a body fluid because $\mathrm{HCO}_{3}{ }^{-}$ions enter or because $\mathrm{OH}^{-}$ions accumulate and react with the $\mathrm{CO}_{2}$ present, i.e., $\mathrm{OH}^{-}+\mathrm{CO}_{2} \rightleftharpoons \mathrm{HCO}_{3}^{-}$. If these reactions occurred in an intestinal lumen whose mucosa was impermeable to $\mathrm{CO}_{2}$, one could infer which of these two mechanisms predominated by determining the difference between lumenal $\mathrm{PCO}_{2}$ values measured at the beginning and end of the period of $\mathrm{HCO}_{2}{ }^{-}$accumulation: transport of $\mathrm{HCO}_{3}^{-}$ions into the fluid would increase the lumenal $\mathrm{PCO}_{2}$ by partial dissociation of $\mathrm{HCO}_{3}{ }^{-}$into $\mathrm{CO}_{2}$ and $\mathrm{OH}^{-}$, and accumulation of $\mathrm{OH}^{-}$ would reduce the $\mathrm{PCO}_{2}$ by removing $\mathrm{CO}_{2}$ from solution as the two combined to form $\mathrm{HCO}_{3}^{-}$. In our studies, however, the mucosa was permeable to $\mathrm{CO}_{2}$, so the final $\mathrm{PCO}_{2}$ of the lumenal fluid could have been affected not only by chemical reactions within the lumenal fluid, but by the $\mathrm{PCO}_{2}$ of fluid in the surrounding mucosa. The $\mathrm{PCO}$ of fluid in mucosal cells is influenced by the interstitial fluid (ISF) ${ }^{1}$ and the rate of cell $\mathrm{CO}_{2}$ production. The basal value of cell $\mathrm{PCO}_{2}$ is determined by the $\mathrm{PCO}_{2}$ of the ISF; the cell adds to this basal value of cell $\mathrm{Pco}_{2}$ by contributing metabolic $\mathrm{CO}_{2}$, or subtracts from the basal value by exporting $\mathrm{CO}_{2}$ at a rate faster than it is produced. In our studies, the final $\mathrm{PCO}_{2}$ of lumenal fluid in the cholera segment decreased significantly, and was lower than arterial $\mathrm{PCO}_{2}$ in 6 of 13 studies. It follows that such a reduction could have been caused primarily by a reduction in the $\mathrm{PCO}_{2}$ of the ISF, cell, or lumenal fluid.

ISF $P_{\mathrm{CO} 2}$. If $\mathrm{HCO}_{3}{ }^{-}$ions were transported from the ISF across the cell into the lumenal fluid (Fig. 4A), the Pcos of the ISF could be reduced to values less than arterial blood, i.e., loss of $\mathrm{HCO}_{3}^{-}$would shift the reaction, $\mathrm{OH}^{-}+\mathrm{CO}_{2} \rightleftharpoons \mathrm{HCO}_{3}^{-}$, to the right. By solving a set of simultaneous equations (Appendix I), it is possible to predict how much the $\mathrm{PCO}_{2}$ would diminish if $\mathrm{HCO}_{3}{ }^{-}$were transported from the ISF at maximal rates. Given that the initial $\mathrm{HCO}_{3}^{-}$concentration of ISF was

${ }^{1}$ Abbreviation used in this paper: ISF, interstitial fluid.
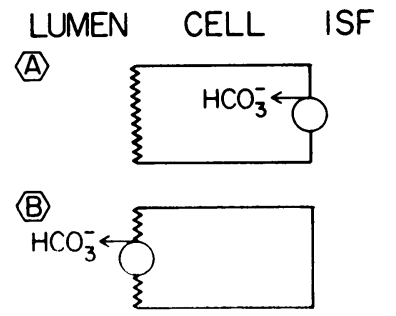

(C)

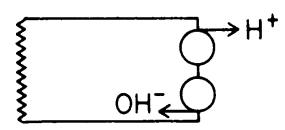

(D)

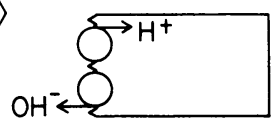

Figure 4 Possible mechanisms of bicarbonate secretion. (A) $\mathrm{HCO}_{3}^{-}$ion pump at the cell-ISF membrane; (B) $\mathrm{HCO}_{3}{ }^{-}$ion pump at the cell-lumen membrane; $(\mathrm{C})$ an ion pump at the cell-ISF membrane that either exports $\mathrm{H}^{+}$ ions or imports $\mathrm{OH}^{-}$ions; (D) an ion pump at the celllumen membrane that either imports $\mathrm{H}^{+}$ions or exports $\mathrm{OH}^{-}$ions.

$18 \mathrm{mM}$ (the mean measured value of arterial $\mathrm{HCO}_{3}^{-}$), a reduction in $\mathrm{HCO}_{3}^{-}$concentration to $1 \mathrm{mM}$ would reduce the ISF $\mathrm{PCO}_{2}$ by 1.1 torr. The entry of $\mathrm{HCO}_{3}{ }^{-}$ ions into the lumenal fluid in an amount that could increase the $\mathrm{HCO}_{3}^{-}$concentration from $25 \mathrm{mM}$ to $65 \mathrm{mM}$ (the initial and final mean concentrations of lumenal $\mathrm{HCO}_{3}{ }^{-}$in the cholera segment) would augment lumenal $\mathrm{PCO}_{2}$ by 7.1 torr in a closed system. The net effect would be to increase lumenal $\mathrm{PcO}_{2}$ by 6 torr. These calculations do not take into account cell $\mathrm{CO}_{2}$ production, which would minimize any reduction in $\mathrm{PCO}_{2}$ in the ISF. Hence, transport of $\mathrm{HCO}_{3}{ }^{-}$ions from the ISF could not explain the observed reduction in $\mathrm{PCO}_{2}$ of lumenal fluid in the cholera segments. These calculations would also apply if a pump for $\mathrm{HCO}_{3}^{-}$ions was located at the celllumen membrane (Fig. 4B), as long as the ultimate source of $\mathrm{HCO}_{3}{ }^{-}$ions was the ISF.

Cell $P_{\text {Co2 }}$. Cellular $\mathrm{Pco}_{2}$ could be reduced if $\mathrm{HCO}_{3}{ }^{-}$ ions were synthesized in the cell by reaction of $\mathrm{OH}^{-}$ with $\mathrm{CO}_{a}$ at the cell-ISF membrane (Fig. 4C). For this process to reduce lumenal $\mathrm{PCO}_{2}$, the rate of $\mathrm{OH}^{-}$ generation must exceed the rate of cell $\mathrm{CO}_{2}$ production and reduce the intracellular $\mathrm{PCO}_{2}$ to values less than that of the lumen. Carbon dioxide would diffuse into the cell and lumenal $\mathrm{PCO}_{2}$ would fall as $\mathrm{HCO}_{3}{ }^{-}$was synthesized. It can be shown that the subsequent movement of the $\mathrm{HCO}_{3}^{-}$ions into the lumen would not increase lumenal $\mathrm{PCO}_{2}$ sufficiently to counteract the $\mathrm{PCO}_{2}$ reduction (See Appendix II).

Lumen $P_{\text {Co2 }}$. Lumenal $\mathrm{PCO}_{2}$ would also diminish if $\mathrm{HCO}^{-}$ions were synthesized on the lumenal side of the cell-lumen membrane (Fig. 4D). As $\mathrm{OH}^{-}$accumulated 
in the lumen, the $\mathrm{CO}_{2}$ from the lumenal fluid and adjacent cell would react to form $\mathrm{HCO}_{3}{ }^{-}$. For lumenal fluid $\mathrm{PCO}_{2}$ to fall below arterial $\mathrm{PCO}_{2}$, the rate of generation of $\mathrm{OH}^{-}$would have to exceed the rate of cell $\mathrm{CO}_{2}$ production. The $\mathrm{PcO}$ of lumenal fluid would fall below arterial $\mathrm{PCO}_{2}$ more readily if the site of $\mathrm{HCO}_{3}^{-}$synthesis is the cell-lumen membrane, because the lumenal fluid and neighboring cytoplasm would be depleted of $\mathrm{CO}_{2}$ before the $\mathrm{CO}_{2}$ from more distal sites was used. If the cell-ISF membrane were the site of synthesis, however, the ISF and basal cytoplasm would be the nearest $\mathrm{CO}_{2}$ source, and it is less likely that lumenal $\mathrm{CO}_{2}$ would be depleted. For these reasons I favor the model shown in Fig. 4D, although it is clear that Fig. 4C cannot be excluded.

Alternative explanations for the reduction in $\mathrm{PCO}_{2}$ in cholera fluid are less acceptable. If the mucosa sieved out the $\mathrm{CO}_{2}$ as water and dissolved $\mathrm{CO}_{2}$ moved from cell (or ISF) to lumen, lumenal $\mathrm{PCO}_{2}$ would decrease. To determine whether such sieving occurs, we induced water movement into the lumen with a hypertonic solution (Table III) and found that the lumenal $\mathrm{PcO}_{2}$ was no less than if an isotonic fluid were being absorbed (Table IV). Although this suggests that sieving does not occur, the study is an imperfect control for two reasons: first, the cell membrane was not exposed to cholera toxin and might have different pore characteristics; and second, in cholera fluid may move into the lumen through crypt cells (2), whereas in the hypertonic studies, water movement may be mostly through villus cells (3). If the route of water movement differs, sieving characteristics may differ. For these reasons, one cannot exclude the possibility that $\mathrm{CO}_{2}$ sieving causes the low lumenal $\mathrm{PCO}_{2}$ in the cholera fluid. In view of the high tissue permeability of $\mathrm{CO}_{2}$, however, sieving seems unlikely

Bicarbonate is the major base that accumulates in the lumen. When the concentrations of $\mathrm{HCO}_{3}^{-}$and total base are compared in the cholera and control segments, $\mathrm{HCO}_{3}^{-}$accounts for most of the base present (Fig. 3). This implies that transport of $\mathrm{OH}^{-}$ions into the lumen (or $\mathrm{H}^{+}$ions out) was the primary event in $\mathrm{HCO}_{3}^{-}$secretion, for if $\mathrm{OH}^{-}$ions had accumulated in the lumen because of the secretion of another basic salt, such as $\mathrm{HPO}_{4}^{-}, \mathrm{HCO}_{3}^{-}$would have accounted for a much smaller fraction of the total base.

Hydroxyl ions could have accumulated in ileal fluid either because $\mathrm{OH}^{-}$ions enter or because $\mathrm{H}^{+}$ions exit (Fig. 4C, D). Although there is an obvious precedent for a hydrogen ion pump in gastric mucosa, there are no compelling reasons to exclude a hydroxyl ion pump in ileal mucosa.

Turnberg, Bieberdorf, Morawski, and Fordtran (4) have proposed that hydrogen ions are secreted into the human ileum as sodium ions are absorbed. A reduction in the rate of $\mathrm{H}^{+}$secretion could explain why the final $\mathrm{PCO}_{2}$ of lumenal fluid in cholera segments was less than that of control segments, but it could not explain why the final $\mathrm{Pco}_{2}$ was less than the $\mathrm{PCO}_{2}$ of arterial blood. Our results could be explained by a "reversal" of such a sodium-hydrogen exchange mechanism, however (4).

Although considerable quantities of mucus are secreted into the cholera segments, it is unlikely that the mucus reduced the lumenal $\mathrm{PcO}$ for two reasons: most of the mucus was drained from the cholera segments before the start of the 45-min study period; and the mucus was probably in equilibrium with ambient $\mathrm{CO}_{2}$ before it was expelled into the lumen.

In the control segments, the final $\mathrm{PCO}_{2}$ of lumenal fluid was higher than the initial $\mathrm{PCO}_{2}$ in 11 of 13 studies, and in no instance was the final $\mathrm{PCO}_{2}$ less than that of arterial blood (Fig. 1). Several factors may have contributed to the increase in lumenal $\mathrm{PCO}_{2}$. First, in most studies, water was absorbed more rapidly than $\mathrm{HCO}_{3}^{-}$; the resultant rise in $\mathrm{HCO}_{3}^{-}$concentration would have shifted the reaction, $\mathrm{OH}^{-}+\mathrm{CO}_{2} \rightleftharpoons \mathrm{HCO}_{3}^{-}$, to the left and increased $\mathrm{PCO}_{2}$. Second, because of the lower rate of $\mathrm{HCO}_{3}^{-}$synthesis and secretion by control segments, less $\mathrm{CO}_{2}$ derived from cell metabolism may have been used in $\mathrm{HCO}_{3}^{-}$synthesis, allowing intracellular Pcoa to rise. Carbon dioxide from the cells would then have diffused into the lumenal fluid and caused Pcos to increase. Third, there may be concurrent secretion of bicarbonate and $\mathrm{H}^{+}$ions as suggested by Turnberg et al. (4). Fourth, the possibility that $\mathrm{HCO}_{3}^{-}$ions are transported into the lumen of control segments cannot be excluded.

The recent demonstrations that the effects of cholera toxin may be mediated by cyclic AMP (5) suggest that the mechanism of bicarbonate secretion observed in the cholera segments is normally present in the cell and is either activated or accelerated by a chain of events initiated by contact of the mucosa with toxin. If that is true, $\mathrm{OH}^{-}$ion accumulation in the cell or lumen may be the normal mechanism of bicarbonate secretion in the small intestine.

\section{APPENDIX I}

With a computer program described by Haglund, Moss, and Flynn (6), it is possible to predict the magnitude of changes that occur in $\mathrm{PcO}_{2}, \mathrm{H}^{+}$, and $\mathrm{HCO}_{3}^{-}$concentrations when the concentrations of $\mathrm{HCO}_{3}^{-}$or $\mathrm{H}^{+}$are changed. The program is an iterative solution of a set of simultaneous equations that characterize the system at equilibrium. The following constants were used in the calculation.

$$
\begin{aligned}
{\left[\mathrm{H}^{+}\right]\left[\mathrm{OH}^{-}\right] } & =K_{w}=2.388 \times 10^{-14}=C_{2} \\
\frac{\left[\mathrm{H}^{+}\right]\left[\mathrm{HCO}_{3}^{-}\right]}{\left[\mathrm{CO}_{2}\right]} & =K_{I}=7.9 \times 10^{-7}=C_{3}
\end{aligned}
$$




$$
\frac{\left[\mathrm{H}^{+}\right]\left[\mathrm{CO}_{3}^{-}-\right]}{\left[\mathrm{HCO}_{3}^{-}\right]}=\mathrm{K}_{I I}=6.6 \times 10^{-11}=C_{4} .
$$

Equilibrium conditions were changed by substituting appropriate values in the equation for charge balance $\left(C_{1}\right)$ and mass balance $\left(C_{0}\right)$, where $C_{1}=\left[\mathrm{H}^{+}\right]-\left[\mathrm{OH}^{-}\right]-$ $\left[\mathrm{HCO}_{3}^{-}\right]-2\left[\mathrm{CO}_{3}^{-}-{ }^{-}\right]$, and $\mathrm{C}_{6}=\left[\mathrm{CO}_{3}\right]+\left[\mathrm{HCO}_{3}{ }^{-}\right]^{\prime}+\left[\mathrm{CO}_{3}{ }^{--}\right]$. In the $\mathrm{pH}$ range of 7-8.3 that characterized the fluids in these studies, the values of $\mathrm{H}^{+}, \mathrm{OH}^{-}$, and $\mathrm{CO}_{3}^{--}$were smaller than $\mathrm{CO}_{2}$ and $\mathrm{HCO}_{3}^{-}$by a factor of at least $10^{2}$, and were not included in the calculations for $C_{1}$ and $C_{8}$.

\section{APPENDIX II}

The average wet weight of ileal segments was $4.6 \mathrm{~g}$. A high estimate of the volume of intracellular mucosal water may be obtained by assuming that $50 \%$ of the total wet weight is composed of intracellular water, or $2.3 \mathrm{ml} / \mathrm{segment}$. The average volume of lumenal fluid in the cholera segments was $5.7 \mathrm{ml}$ during the $45-\mathrm{min}$ study period. If the mucosal cell mass is a closed system with an intracellular milieu similar to arterial plasma, and the intracellular $\mathrm{OH}^{-}$ concentration was increased by $1 \mathrm{mM}$ by transport at the cell-ISF membrane, the intracellular concentration of $\mathrm{HCO}_{3}^{-}$would increase by $0.6 \mathrm{mM}$ (from 25 to $25.6 \mathrm{mM}$ ) and intracellular $\mathrm{PCO}_{2}$ would decrease from 40 to 14 torr. If the freshly synthesized $\mathrm{HCO}_{3}^{-}$then moved from the cells into the $5.7 \mathrm{ml}$ of lumenal fluid, the $\mathrm{HCO}_{3}{ }^{-}$concentration of lumenal fluid would increase by $0.24 \mathrm{mM}$ and cause a rise in lumenal $\mathrm{PCO}_{2}$ too trivial to be measured by our methods. In response to the marked reduction in intracellular $\mathrm{PCO}_{2}$, however, $\mathrm{CO}_{2}$ would diffuse from the lumen into the cells and lumenal $\mathrm{PCO}_{2}$ would diminish. In that manner, synthesis of $\mathrm{HCO}_{3}^{-}$at the cell-ISF membrane could reduce the lumenal fluid $\mathrm{PCO}_{2}$.

\section{ACKNOWLEDGMENTS}

The author is indebted to Mary Denton for her skilled assistance, and for the diligence and care with which she performed these studies.

This work was supported in part by U. S. Public Health Service Grants AM 09022 and AM 5390 from the $\mathrm{Na}$ tional Institute of Arthritis Metabolism and Digestive Disease.

\section{REFERENCES}

1. Banwell, J. G., N. F. Pierce, R. C. Mitra, K. L. Brigham, G. J. Caranasos, R. I. Keimowitz, D. S. Fedson, J. Thomas, S. L. Gorback, R. B. Sack, and A. Mondal. 1970. Intestinal fluid and electrolyte transport in human cholera. J. Clin. Invest. 49: 183.

2. Roggin, G. M., J. G. Banwell, J. H. Yardley, and T. R. Hendrix. 1972. Unimpaired response of rabbit jejunum to cholera toxin after selective damage to villus epithelium. Gastroenterology. $63: 981$.

3. Loeschke, K., C. J. Bentzel, and T. Z. Csáky. 1970. Asymmetry of osmotic flow in frog intestine: functional and structural correlation. Am. J. Physiol. 218: 1723 .

4. Turnberg, L. A., F. A. Bieberdorf, S. G. Morawski, and J. S. Fordtran. 1970. Interrelationships of chloride, bicarbonate, sodium, and hydrogen transport in the human ileum. J. Clin. Invest. 49: 557.

5. Kimberg, D. V., M. Field, J. Johnson, A. Henderson, and E. Gershon. 1971. Stimulation of intestinal mucosa adenyl cyclase by cholera enterotoxin and prostaglandins. J. Clin. Invest. 50: 1218.

6. Haglund, E., D. Moss, and J. Flynn. 1966. General solution of ionic equilibria problems. J. Chem. Educ. 43: 582 . 